\title{
Burnout and nursing work environment in public health institutions
}

\author{
Burnout e ambiente de trabalho de enfermeiros em instituições públicas de saúde \\ Burnout y el ambiente de trabajo de los enfermeros en instituciones públicas de salud
}

\begin{abstract}
Lilia de Souza Nogueira', Regina Márcia Cardoso de Sousa', Erika de Souza Guedes', Mariana Alvina dos Santos", Ruth Natalia Teresa Turrini', Diná de Almeida Lopes Monteiro da Cruz'

'Universidade de São Paulo, School of Nursing, Department of Medical-Surgical Nursing. São Paulo, Brazil. "Universidade Federal de Mato Grosso do Sul, Department of Nursing. Três Lagoas, Mato Grosso do Sul, Brazil.
\end{abstract}

How to cite this article:

Nogueira LS, Sousa RMC, Guedes ES, Santos MA, Turrini RNT, Cruz DALM. Burnout and nursing work environment in public health institutions. Rev Bras Enferm [Internet]. 2018;71(2):336-42. DOI: http://dx.doi.org/10.1590/0034-7167-2016-0524

Submission: 11-08-2016

Approval: 05-02-2017

\section{ABSTRACT}

Objective: to identify associations between the Burnout domains and the characteristics of the work environment. Method: cross-sectional study with 745 nurses from 40 public health institutions in São Paulo. Nursing Work Index-Revised (NWI-R) and Maslach Burnout Inventory were used. Similar institutions according to NWI-R were grouped by clustering and the Anova and Bonferroni tests were used in the comparative analyzes. Results: there was significant and moderate correlation between emotional exhaustion and autonomy, control over the environment and organizational support; between reduced personal accomplishment, autonomy and organizational support; and between depersonalization and autonomy. The group that presented the worst conditions in the work environment differed on emotional exhaustion from the group with most favorable traits. Conclusion: emotional exhaustion was the trait of Burnout that was more consistently related to the group of institutions with more unfavorable working conditions regarding autonomy, organizational support and control over the environment.

Descriptors: Burnout, Professional; Nursing; Health Facility Environment; Hospitals, Public; Cross-Sectional Studies.

\section{RESUMO}

Objetivo: identificar associações entre os domínios do Burnout e as características do ambiente de trabalho. Método: estudo transversal com 745 enfermeiros de 40 instituições públicas de saúde de São Paulo. Nursing Work Index-Revised (NWI-R) e Maslach Burnout Inventory foram utilizados. Instituições semelhantes, segundo NWI-R, foram agrupadas pelo método de Cluster e os testes Anova e Bonferroni foram aplicados nas análises comparativas. Resultados: houve correlação significativa e moderada entre exaustão emocional e autonomia, controle sobre o ambiente e suporte organizacional; baixa realização pessoal e autonomia, e suporte organizacional; despersonalização e autonomia. O grupo que apresentou as piores condições de ambiente de trabalho diferiu do que teve os mais favoráveis atributos quanto à exaustão emocional. Conclusão: a exaustão emocional foi o traço do Burnout que se relacionou de forma mais constante com o grupo de instituições com condições mais desfavoráveis de trabalho quanto à autonomia, suporte organizacional e controle sobre o ambiente.

Descritores: Esgotamento Profissional; Enfermagem; Ambiente de Instituições de Saúde; Hospitais Públicos; Estudos Transversais.

\section{RESUMEN}

Objetivo: identificar asociaciones entre los dominios de Burnout y las características del ambiente de trabajo. Método: estudio transversal entre 745 enfermeros de 40 instituciones públicas de salud de São Paulo. Se utilizaron, la Escala Adaptada del Entorno de Práctica Enfermera (Nursing Work Index-Revised, NWI-R) y el cuestionario Maslach Burnout Inventory. Se agruparon instituciones semejantes por el método de Cluster, según la NWI-R y se aplicaron las pruebas Anova y Bonferroni en los análisis comparativos. Resultados: hubo correlación significativa y moderada entre agotamiento emocional y autonomía, control sobre el ambiente y soporte organizacional; baja realización personal y autonomía y soporte organizacional; despersonalización y autonomía. El grupo que presentó las peores condiciones de ambiente de trabajo se diferenció del que tuvo los atributos más favorables con relación al agotamiento emocional. Conclusión: el agotamiento emocional fue la característica de Burnout que 
se relacionó de forma más constante con el grupo de instituciones en condiciones de trabajo más desfavorables respecto a la autonomía, soporte organizacional y control sobre el ambiente.

Descriptores: Agotamiento Profesional; Enfermería; Ambiente de Instituciones de Salud; Hospitales Públicos; Estudios Transversales.

\section{CORRESPONDING AUTHOR Lilia de Souza Nogueira E-mail: lilianogueira@usp.br}

\section{INTRODUCTION}

Burnout is a reaction to chronic stress at work. It has negative socioeconomic consequences and affects the worker's physical and mental health ${ }^{(1-3)}$. This condition has been reported among nursing professionals, who are often in contexts of dynamic work, overburden and intense interpersonal relationships, which makes them susceptible to developing Burnout ${ }^{(1-2,4)}$. It is important to deepen the understanding of the factors associated with this syndrome in order to find strategies to prevent it, which would benefit the health of the worker and the quality of care.

Theoretically, Burnout depends on individual susceptibility and on the environment in which the professional is inserted, including the daily workplace and the society to which the individual belongs ${ }^{(5)}$. Interventions that increase personal resources to cope with environmental challenges can help control this syndrome. However, interventions can be better targeted at the daily work environment, the structure and the functions that organize $i{ }^{(5)}$ than in the other conditions related to Burnout, so the former have been of more interest to scholars in this area. Analyses on the subject ${ }^{(6)}$ have pointed out that Burnout is mainly determined by inadequate organization of work, which can result in work overload, lack of autonomy and lack of support for tasks.

The nursing work environment has been studied by different researchers through the application of instruments such as the Nursing Work Index-Revised, which allows to describe this environment in four components: autonomy, control over the environment, physician-nurse relationship and organizational support ${ }^{(7)}$.

Research has shown that the negative aspects of the work environment are related to adverse events associated with low quality care $^{(4)}$ and can increase the risk of undesirable consequences, such as Burnout ${ }^{(8)}$.

Since the 1980s, researchers from the United States have been investigating the influence of the characteristics of the work environment on the outcomes obtained with nursing professionals and patients ${ }^{(9)}$. In Brazil, studies found an association between work environment and Burnout ${ }^{(8,10)}$. However, these investigations did not assess the profile of the work environment that is associated with the syndrome.

Assessing this profile will support the elaboration of hypotheses to identify and prevent the Burnout. Therefore, this study aims to identify the associations between the three domains of Burnout and the characteristics of the work environment of the nurse.

\section{METHOD}

\section{Ethical aspects}

The project was approved by the Research Ethics Committee and a Consent Term was signed by the research subjects.

\section{Design, place of study and period}

This is a cross-sectional study with quantitative approach, carried out in public health institutions under the direct administration of the Health Services Coordination Office of the State Department of Health of São Paulo, Brazil, between January 2011 and January 2012.

\section{Population and sample: inclusion criteria}

Of the 43 institutions linked to the Health Services Coordination Office of the State Department of Health of São Paulo during the data collection period, 40 accepted to participate in the study: 18 (45.0\%) were general hospitals, 15 (37.5\%) were specialized hospitals, $4(10.0 \%)$ were specialized care centers, $2(5.0 \%)$ were polyclinics and $1(2.5 \%)$ was a day hospital. Institutions with hospitalization units predominated (85.0\%) and, among those, $55.0 \%$ were large (150 to 500 beds), $27.5 \%$ were medium (50 to 149 beds) and only one (2.5\%) was small (24 to 49 beds). Most of the institutions (70,0\%) accepted all patients and $12(30,0 \%)$ only accepted referred patients.

The convenience sample was composed of 745 baccalaureate nurses who worked in different sectors that provided direct assistance to the patients in the institution.

The professionals who were on leave during the study period were not included.

\section{Study variables}

The study included the variables: gender; age; mean time of formal education and length of service in the institution; Burnout, assessed by the Maslach Burnout Inventory (MBI) according to its components (emotional exhaustion, depersonalization and reduced personal accomplishment) ${ }^{(6)}$ and the institution's organizational traits according to NWI-R subscales (autonomy, control over the environment, physician-nurse relationship and and organizational support) ${ }^{(7)}$.

\section{Study protocol}

The physical and emotional exhaustion of the nurse was assessed through the version of the MBI for healthcare workers. This instrument evaluates the feelings of the participants about their work in 22 items distributed in three domains: emotional exhaustion, depersonalization and reduced personal accomplishment. In the first two domains, higher scores correspond to greater feelings of emotional exhaustion and depersonalization. In the reduced personal accomplishment domain, higher scores indicate high personal accomplishment. In this study, no cut-off points were used for diagnosing Burnout, according the recommendation of the $\mathrm{MBI}$ authors, since research could not identify a score pattern that indicates individual dysfunction or need for intervention ${ }^{(6)}$.

The version of the $\mathrm{MBI}$ used consisted of a five-point Likert scale ${ }^{(1-5)}$, different from the original instrument with seven 
categories. The choice for this version of the instrument was due to the difficulties observed among Brazilian respondents to discriminate the seven categories of the original instrument $^{(11)}$. In the application of the five-category $\mathrm{MBI}$, the scores of the domains had the following ranges: emotional exhaustion, nine to 45 ; depersonalization, five to 25 ; and reduced personal accomplishment, eight to $40^{(11)}$.

The version of the NWI- $R^{(7)}$ translated and validated in Brazil was used to investigate the organizational traits of the institutions ${ }^{(10)}$. This instrument assesses the characteristics of a work environment that is supportive of nursing practice. It is composed of 57 items, of which 15 are distributed in 4 subscales: autonomy, control over the environment, nursephysician relationship and organizational support ${ }^{(10)}$.

The subscales autonomy and control over the environment represent the freedom of nurses to solve problems that affect the quality of nursing care. The subscale nurse-physician relationship addresses the professional respect necessary for an effective communication, which allows reaching the common objective of providing adequate care to the patient. Finally, organizational support consists of items derived from the subscales above and allows identifying the situations in which the organization provides support to nursing practice ${ }^{(7,10,12)}$. The scores of these subscales vary from one to four points, and in the Brazilian version of the NWI-R, lower values indicate that the institution has more favorable characteristics for nursing practice $^{(10)}$.

Data were collected by trained research assistants and supervised by one of the researchers. The instruments were filled out by the nurses during their work shifts and the research assistants were available for doubts during this process. At that time, besides the $\mathrm{MBI}$ and the NWI-R, a socio-demographic questionnaire was also applied.

\section{Analysis of results and statistics}

The reliability of the $\mathrm{MBI}$ and the NWI-R instruments was assessed using the Cronbach's alpha coefficient, and values above 0.7 were considered satisfactory. Descriptive statistics were used for the characterization of the sample and description of the values obtained by the nurses in the MBI domains and the NWI-R subscales. The Pearson correlation coefficient was used to verify the relationship between the work environment (NWI-R) and Burnout (MBI). The following intervals were used to interpret the strength of these relationships: values reaching 1.0 were considered perfect, values between 0.90 and 0.60 were considered strong, values between 0.59 and 0.30 were considered moderate and values below 0.30 were considered weak ${ }^{(13)}$.

K-means clustering was performed using Euclidean distance to identify groups of institutions with similar work environments, according to the four NWI-R subscales. Analysis of variance (ANOVA) was conducted to compare the MBI scores between these groups. For using this test, homogeneity of variance among the groups was verified (assumption required for the test). In the situation where there was a significant difference among the means of the groups, multiple comparisons (pairwise comparisons) were made using the Bonferroni test to isolate where those difference are. The significance level was set at $5 \%$ was applied for all analyses.

\section{RESULTS}

The $\mathrm{MBI}$ was answered by 745 baccalaureate nurses, most of them female $(86.7 \%)$, with a mean age of 43 years $(\mathrm{SD}=9.6)$. The mean time of formal education was 14 years $(S D=8.5)$, and the mean length of service in the institution was nine years $(S D=9.4)$.

The reliability results of the NWI-R and the MBI, measured by the Cronbach's alpha, are shown in Table 1. In the MBI, the coefficients ranged from 0.55 to 0.88 , and the domain depersonalization was the only one that presented a coefficient below satisfactory. The values of the NWI-R subscales ranged between 0.70 and 0.82 .

Table 1 - Reliability of the Maslach Burnout Inventory (MBI) and the Nursing Work Index-Revised (NWI-R), São Paulo, Brazil, 2011-2012

\begin{tabular}{lcc} 
Instrument & $\begin{array}{c}\text { Number } \\
\text { of items }\end{array}$ & $\begin{array}{c}\text { Cronbach's } \\
\text { Alpha }\end{array}$ \\
\hline MBI & & \\
$\quad$ Emotional exhaustion & 9 & 0.88 \\
$\quad$ Depersonalization & 5 & 0.55 \\
$\quad$ Reduced personal accomplishment & 8 & 0.72 \\
NWI-R & & \\
$\quad$ Autonomy & 5 & 0.70 \\
$\quad$ Control over the environment & 7 & 0.79 \\
$\quad$ Physician-nurse relationship & 3 & 0.78 \\
$\quad$ Organizational support & 10 & 0.82
\end{tabular}

Note: MBI: Maslach Burnout Inventory; NWI-R: Nursing Work Index-Revised

The analysis using descriptive statistics of the level of Burnout and the professional practice environment, according to the NWI-R, is presented in Table 2.

In Table 3 it is possible to observe that there was a statistically significant correlation between autonomy and all MBI domains. No MBI domain was associated with the NWI-R subscale physician-nurse relationship. Control over the environment was correlated with the emotional exhaustion domain; and the subscale organizational support was associated with emotional exhaustion and with reduced personal accomplishment. All the correlations observed were moderate but positive when related to the emotional exhaustion and depersonalization domains and negative when related to reduced personal accomplishment.

In the Cluster analysis, four groups of institutions with similar work environment profiles were identified, based on the four NWI-R subscales and with the following distribution: group 1 (n $=8,20.0 \%)$, group $2(\mathrm{n}=16,40.0 \%)$, group $3(\mathrm{n}=13,32.5 \%)$, and group $4(n=3,7.5 \%)$. The characterization of these groups indicated that the institutions in group 1 presented more favorable work environments; group 2 presented intermediate values for all four subscales; group 3 presented the highest values in the subscale physician-nurse relationship, indicating unfavorable professional relationships; and group 4 presented an unfavorable environment for three subscales (autonomy, control over the environment and organizational support). 
Table 2 - Descriptive statistics of the Maslach Burnout Inventory (MBI) domains and the Nursing Work Index-Revised (NWI-R) subscales, São Paulo, Brazil, 2011-2012

\begin{tabular}{|c|c|c|c|c|}
\hline Domain - MBI & Mean & Standard Deviation & Median & Range \\
\hline Emotional exhaustion & 22.4 & 6.5 & 22 & $9-45$ \\
\hline Depersonalization & 8.9 & 3.1 & 9 & $5-21$ \\
\hline Reduced personal accomplishment & 31.4 & 4.3 & 32 & $14-40$ \\
\hline Subscales - NWI-R & Mean & Standard Deviation & Median & Range \\
\hline Autonomy & 2.0 & 0.3 & 2.0 & $1.4-3.2$ \\
\hline Control over the environment & 2.4 & 0.4 & 2.3 & $1.5-3.1$ \\
\hline Physician-nurse relationship & 2.1 & 0.3 & 2.1 & $1.5-2.9$ \\
\hline Organizational support & 2.1 & 0.3 & 2.1 & $1.5-2.8$ \\
\hline
\end{tabular}

Note: MBI: Maslach Burnout Inventory; NWI-R: Nursing Work Index-Revised

Table 3 - Pearson correlation coefficients between Nursing Work Index-Revised (NWI-R) and Maslach Burnout Inventory (MBI), São Paulo, Brazil, 2011-2012

\begin{tabular}{|c|c|c|c|c|}
\hline MBI & Autonomy & Control over the environment & Physician-nurse relationship & Organizational support \\
\hline Emotional exhaustion & $\begin{array}{c}0.46 \\
p=0.003\end{array}$ & $\begin{array}{c}0.39 \\
\mathrm{p}=0.013\end{array}$ & $\begin{array}{c}0.24 \\
\mathrm{p}=0.134\end{array}$ & $\begin{array}{c}0.40 \\
\mathrm{p}=0.010\end{array}$ \\
\hline Depersonalization & $\begin{array}{c}0.33 \\
\mathrm{p}=0.039\end{array}$ & $\begin{array}{c}0.19 \\
\mathrm{p}=0.229\end{array}$ & $\begin{array}{c}0.13 \\
p=0.439\end{array}$ & $\begin{array}{c}0.27 \\
p=0.087\end{array}$ \\
\hline Reduced personal accomplishment & $\begin{array}{c}-0.44 \\
p=0.004\end{array}$ & $\begin{array}{c}-0.26 \\
\mathrm{p}=0.104\end{array}$ & $\begin{array}{c}-0.11 \\
\mathrm{p}=0.516\end{array}$ & $\begin{array}{c}-0.40 \\
\mathrm{p}=0.011\end{array}$ \\
\hline
\end{tabular}

Note: NWI-R: Nursing Work Index-Revised; MBI: Maslach Burnout Inventory

Table 4 - Comparison of work environment groups according to Maslach Burnout Inventory (MBI)results, São Paulo, Brazil, 2011-2012

\begin{tabular}{|c|c|c|c|c|c|c|}
\hline \multirow{2}{*}{ MBI } & & \multicolumn{4}{|c|}{ NWI - R } & \multirow{2}{*}{$p$ value* } \\
\hline & & Group 1 (n-8) & Group $2(n=16)$ & Group $3(n=13)$ & Group $4(n=3)$ & \\
\hline Emotional exhaustion & $\begin{array}{c}\text { Média } \\
\text { DP }\end{array}$ & $\begin{array}{c}21,1 \\
1,3\end{array}$ & $\begin{array}{c}22,4 \\
1,5\end{array}$ & $\begin{array}{c}22,4 \\
2,9\end{array}$ & $\begin{array}{c}25,4 \\
0,6\end{array}$ & 0,035 \\
\hline Depersonalization & $\begin{array}{c}\text { Média } \\
\text { DP }\end{array}$ & $\begin{array}{l}8,9 \\
0,8\end{array}$ & $\begin{array}{l}8,4 \\
0,9\end{array}$ & $\begin{array}{l}8,7 \\
0,9\end{array}$ & $\begin{array}{c}10,2 \\
0,7\end{array}$ & 0,028 \\
\hline Reduced personal accomplishment & $\begin{array}{c}\text { Média } \\
\text { DP }\end{array}$ & $\begin{array}{c}32,4 \\
1,1\end{array}$ & $\begin{array}{c}31,8 \\
1,6\end{array}$ & $\begin{array}{c}31,7 \\
1,0\end{array}$ & $\begin{array}{c}30,3 \\
1,7\end{array}$ & 0,154 \\
\hline
\end{tabular}

Nota: MBI: Maslach Burnout Inventory; NWI-R: Nursing Work Index-Revised; DP: Desvio Padrão; ${ }^{*}$ Teste ANOVA

Table 5 - Results of the multiple comparisons for the domains emotional exhaustion and depersonalization, São Paulo, Brasil, 2011-2012

\begin{tabular}{ccc}
\hline Comparisons & Emotional exhaustion $\left(\boldsymbol{p}\right.$ value $\left.{ }^{*}\right)$ & Depersonalization $\left(\boldsymbol{p}\right.$ value $\left.{ }^{*}\right)$ \\
\hline Group 1 x Group 2 & 0.981 & $>0.999$ \\
Group 1 x Group 3 & $>0.999$ & $>0.999$ \\
Group 1 x Group 4 & $\mathbf{0 . 0 2 3}$ & 0.293 \\
Group 2 x Group 3 & $>0.999$ & $>0.999$ \\
Group 2 x Group 4 & 0.149 & $\mathbf{0 . 0 2 1}$ \\
Group 3 x Group 4 & 0.167 & 0.094 \\
\hline
\end{tabular}

Note: * Bonferroni Test

It is possible to observe in table 4 that the groups differed significantly in the Burnout domains of emotional exhaustion and depersonalization $(p<0.05)$. Group 4 stood out from the others because it presented the highest mean of emotional exhaustion and depersonalization, and the lowest mean of reduced personal accomplishment. Therefore, the nurses of the institutions in this group were more exhausted and with more intense feelings of depersonalization and reduced personal accomplishment.

The multiple comparisons made using the Bonferroni test, which are presented in Table 5, showed that group 4 differed 
significantly from groups 1 and 2 . The analysis of this result along with the results from Table 4 show that group 4 had means higher than group 1 regarding emotional exhaustion $(p=0.023)$ and higher than group 2 regarding depersonalization $(p=0.021)$.

\section{DISCUSSION}

A professional activity should be a source of satisfaction, economic and professional achievement, and it should emphasize the important role of the individual in society. However, daily practice is experienced with different levels of occupational stress, which may lead to the development of the Burnout syndrome.

Age and length of service are factors that have been inversely related to Burnout ${ }^{(5)}$. Thus, younger and newly admitted people are more likely to have this syndrome. Participants in this investigation had a mean age of 43 years $(S D=9.6)$, and length of service of nine years $(S D=9.4)$; thus, their individual characteristics did not indicate susceptibility to occupational burnout.

However, the mean and median values resulting from the application of the $\mathrm{MBI}$ indicated moderate emotional exhaustion (mean $22.4 \pm 6.5$ ) and depersonalization (mean 8.9 \pm 3.1 ) and reduced personal accomplishment (mean $31.4 \pm 4.3$ ). Scores between 16 and 25 and 7 and 12 indicated moderate emotional exhaustion and depersonalization, respectively. For the third domain, scores smaller than 32 indicated a low sense of personal accomplishment ${ }^{(14)}$.

The variation of the scores observed in the sample (Table 1) indicates the presence of individuals with high emotional exhaustion and depersonalization and reduced personal accomplishment, indicated by the maximum scores of, respectively, 45, 21 and 40 .

Regarding the work environment, this study found values close to 2 in all NWI-R subscales, results similar to Brazilian investigations carried out in Intensive Care Units ${ }^{(8,12,15)}$ and better than those observed in a study carried out in Primary Care Units ${ }^{(16)}$.

In the comparison with other countries, the work environment described by the NWI-R in Brazil(8,12,15-16) presents worse characteristics than the ones found in an Irish study which, in turn, found less favorable environments than those observed in north american institutions ${ }^{(17)}$.

An integrative review in the Brazilian journals identified that deficient infrastructure, lack of equipment, dissatisfaction with salary, overload of tasks, inadequate staff sizing and the resulting exhausting work process, lack of professional recognition, among others, are factors that influence the quality of life of nurses working in hospital institutions ${ }^{(18)}$.

Another literature review, which included studies published between 2010 and 2014 mainly in Brazil, showed that deficit of staff, work overload, relationship problems in the multiprofessional team, lack of leadership, among others, are the main causes of adverse events in nursing care ${ }^{(19)}$.

The two reviews descrived above identify unfavorable work environment conditions in the Brazilian context, which may result in physical and/or emotional exhaustion and may impair the quality of the assistance provided to patients.

In the present study, the nurses presented symptoms of Burnout and were working in environments with aspects unfavorable to the professional practice. Unfavorable environments in terms of autonomy, control over the environment and organizational support were more strongly associated with high emotional exhaustion, a component that is considered the nucleus ${ }^{(3)}$ and initial sign of the syndrome ${ }^{(20)}$.

Autonomy was the only NWI-R subscale that was correlated with all components of Burnout, whereas the relationships between physicians and nurses were not associated with the condition (Table 3). As described in the method, the autonomy subscale represents the freedom of nurses to solve problems that affect the quality of nursing care. Higher values in this subscale indicate unfavorable characteristics for nursing practice ${ }^{(7,10,12)}$. This is similar to the interpretation of the emotional exhaustion and depersonalization scores of the $\mathrm{MBI}$ (the higher the score, the greater the feeling of exhaustion and depersonalization perceived by the nurses). Therefore, the results of Table 3 show that there is a direct and positive relationship between autonomy and Burnout, in the sense that a greater sense of autonomy can have a protective effect on the development of Burnout. This hypothesis is also supported by the results of Table 3, which show that autonomy has a protective effect on reduced personal accomplishment since, in the case of this $\mathrm{MBI}$ domain, higher scores indicate high personal accomplishment. The correlation coefficient between autonomy and personal accomplishment was negative $(-0.44, p=0.004$, Table 3), which means that the greater the sense of autonomy, the greater the perception of personal accomplishment.

In the NWI-R validation for the Brazilian contex ${ }^{(10)}$, the correlations between this index and the $\mathrm{MBI}$ were tested. The level of significance was reached between almost all domains and subscales of the instruments. However, some similarities with the results of the this study were verified: low intensity or absent correlation between the nurse-physician relationship and the depersonalization (0.11) and reduced personal accomplishment (-0.25) domains; in addition, the highest coefficients were found in the correlations between emotional exhaustion and autonomy (0.37), control over the environment $(0.49)$ and organizational support (0.45)

In the comparison between the groups of institutions formed according to NWI-R results, the institutions in group 4, with worse working conditions regarding autonomy, control over the environment and organizational support, presented the highest emotional exhaustion scores, different from group 1, which was composed of institutions with better work environments.

This result and the correlation between NWI-R and MBI confirm the assumption that unfavorable work environments are associated with emotional exhaustion. The prominent and consistent behavior of this Burnout aspect found in this and other studies ${ }^{(8,10)}$ probably indicates its nuclear role in relation to the other domains of the syndrome. It is worth mentioning that depersonalization has been considered a behavioral defense mechanism against emotional exhaustion and reduced personal accomplishment, as another consequence of Burnout ${ }^{(3)}$.

These observations may contribute to prevalence analyses, since these studies apply different criteria to diagnose Burnout: for some, this condition is defined by the presence of a significant alteration in the three $\mathrm{MBI}$ domains; for others, an alteration in one of the domains is already a sign of Burnout. A study carried out in a hospital in the south of Brazil(21), did not find the syndrome among the interviewees when it applied the criterion of significant alterations in the three domains. However, the prevalence 
reached $35.7 \%$ when only one of the components was sufficient for diagnosis. According to the authors, other studies that used the more rigid criteria also presented lower Burnout rates than this last result. Therefore, the question remains whether the presence of the Burnout triad is really necessary for its diagnosis.

In addition, there was no clear relationship between the characteristics of the work environment and depersonalization; the group with unfavorable conditions (group 4) differed from the intermediate group (group 2); however, the same did not occur when it was compared to the group of institutions with better working conditions (group 1). Perhaps depersonalization is more strongly related to individual response to emotional exhaustion, since it has been considered a coping strategy and a natural mechanism against exhaustion ${ }^{(22)}$. However, there are arguments against considering depersonalization as a coping strategy ${ }^{(3)}$ since, if it were a healthy defense, it would be negatively associated with emotional exhaustion rather than positively, as it has been observed.

Furthermore, the reliability results observed in $\mathrm{MBI}$ had satisfactory coefficients in the areas of emotional exhaustion and reduced personal accomplishment; however, the Cronbach's alpha of the depersonalization domain indicated fragility. Similarly, low reliability values in the depersonalization domain were identified in other studies: $0.54^{(8)}$ and $0.65^{(23)}$.

\section{Limitations of the study}

It is worth mentioning as a limitation of this investigation that the professionals who were on leave during the study period did not participate. The inclusion of these professionals in the research could change the extent of the burnout aspects. In addition, the research data refer to the health institutions of the state's public administration, so the characteristics of the management model, the assistance standards and the clinical characteristics of the patients may be directly related to the results found. Despite the similarity between nursing settings found in a study about work environments in Brazilian public and private Intensive Care Units, this restriction should be considered, since this research refers to a type of unit of these institutions ${ }^{(12)}$.

In Brazil, one difficulty in investigating the nursing work environment lies in the varying levels of compatibility between the NWI-R subscales applied in national studies and those used in other countries ${ }^{(12)}$. International studies use the Practice Environment Scale (PES)(24) more frequently, which was created from the NWI-R but has not yet been validated for the Brazilian context. Moreover, in countries such as Spain ${ }^{(25)}$ and South Korea ${ }^{(26)}$, the factor analysis of the validated versions of the instrument identified different NWI-R and PES subscales, making the comparison of results even more complex.

\section{Contributions to the Nursing area}

From the above, it is possible to say that emotional exhaustion, which has been related in a more constant and linear way with the characteristics of the environment, can be an alert for the need to identify inappropriate aspects in the work environment. In the management of nursing services, it is important to provide favorable conditions in the organizational environment, in order to promote the autonomy of the professionals, increase their control over the environment and improve the organizational support offered to them. The results suggest that environments with these conditions are less susceptible to Burnout, a syndrome that can impair the quality of care.

\section{CONCLUSION}

The characteristics of the work environment that were related to Burnout were: autonomy, organizational support and control over the environment. The lack of autonomy to solve work problems was associated with the three components that characterize the Burnout; the organization's lack of support for the professional practice was associated to reduced personal accomplishment and emotional exhaustion, and low control over the environment was associated only with the latter.

Emotional exhaustion was more intense in the group of institutions with worst working conditions regarding autonomy, organizational support and control over the environment, than in the group with the most favorable conditions for nursing practice. In addition, the negative attitude of depersonalization was also more present in the group of institutions with unfavorable characteristics than in the institutions with intermediate profiles.

Future studies should address other variables potentially associated with Burnout, besides the organizational traits identified by the NWI-R, such as: type of patient, hospital unit, public or private administration, among others. Studies addressing the score patterns of nursing Burnout would be particularly useful to identify the syndrome and the need for early intervention.

\section{FUNDING}

São Paulo Research Foundation - FAPESP (Process no. 2010/02985-6) and National Council for Scientific and Technological Development - CNPq (Process no. 491728).

\section{REFERENCES}

1. Lorenz VR, Benatti MCC, Sabino MO. Burnout and Stress Among Nurses in a University Tertiary Hospital. Rev Latino-Am Enfermagem [Internet]. 2010 [cited 2016 Jun 08];18(6):1084-91. Available from: http://www.scielo.br/pdf/rlae/v18n6/07.pdf

2. Schmidt DRC, Paladini M, Biato C, Pais JD, Oliveira AR. [Quality of working life and burnout among nursing staff in Intensive Care Units]. Rev Bras Enferm [Internet]. 2013 [cited 2016 Jun 08];66(1):13-7. Available from: http://www.scielo.br/pdf/reben/v66n1/ v66n1a02.pdf Portuguese

3. Vieira I. Conceito(s) de burnout: questões atuais da pesquisa e a contribuição da clínica. Rev Bras Saúde Ocup [Internet]. 2010 [cited 2016 Jun 08];35(122):269-76. Available from: http://www.scielo.br/pdf/rbso/v35n122/a09v35n122.pdf 
4. Van Bogaert P, Timmermans O, Weeks SM, van Heusden D, Wouters K, Franck E. Nursing unit teams matter: impact of unit-level nurse practice environment, nurse work characteristics, and burnout on nurse reported job outcomes, and quality of care, and patient adverse events-a cross-sectional survey. Int J Nurs Stud[Internet] 2014 [cited 2016 Jun 08];51(8):1123-34. Available from: http://www.journalofnursingstudies.com/article/S0020-7489(13)00387-8/pdf

5. Vega NV, Sanabria A, Domínguez LC, Osorio C, Bejarano M. Síndrome de desgaste profesional. Rev Colomb Cir[Internet]. 2009 [cited 2016 Jun 08];24(3):138-46. Available from: http://www.scielo.org.co/pdf/rcci/v24n3/v24n3a2.pdf

6. Maslach C, Jackson SE, Leiter M: Maslach Burnout Inventory Manual. $3^{\text {rd }}$.ed. Palo Alto, CA: Consulting Psychologist's Press; $1996.51 \mathrm{p}$.

7. Aiken LH, Patrician PA. Measuring organizational traits of hospitals: the Revised Nursing Work Index. Nurs Res. 2000;49(3):146-53.

8. Panunto MR, Guirardello EdB. Professional nursing practice: environment and emotional exhaustion among intensive care nurses. Rev Latino-Am Enfermagem [Internet]. 2013 [cited 2016 Jun 08];21(3):765-72. Available from: http://www.scielo.br/pdf/rlae/ v21n3/0104-1169-rlae-21-03-0765.pdf

9. Van den Heede K, Aiken LH. Nursing workforce a global priority area for health policy and health services research: a special issue. Int J Nurs Stud [Internet]. 2012[cited 2016 Jun 08];50(2):141-2. Available from: http://dx.doi.org/10.1016/j.ijnurstu.2012.04.015

10. Gasparino RC, Guirardello Ede B, Aiken LH. Validation of the Brazilian version of the Nursing Work Index-Revised (B-NWI-R). J Clin Nurs [Internet]. 2011 [cited 2016 Jun 08];20(23-24):3494-501. Available from: http://dx.doi.org/10.1111/j.1365-2702.2011.03776.x

11. Tamayo RM. Relação entre a síndrome de Burnout e os valores organizacionais no pessoal de enfermagem de dois hospitais públicos [Dissertação]. Brasília (DF): Universidade de Brasília; 1997. 102p.

12. Balsanelli AP, Cunha ICKO. The work environment in public and private intensive care units. Acta Paul Enferm[Internet]. 2013[cited 2016 Jun 08];26(6):561-8. Available from: http://dx.doi.org/10.1590/S0103-21002013000600009

13. Levin RF, Lunney M, Krainovich-Miller B. Improving diagnostic accuracy using an evidence-based nursing model. Int J Nurs Terminol Classif [Internet]. 2004[cited 2016 Jun 08];15(4):114-22. Available from: http://dx.doi.org/10.1111/j.1744-618X.2004. tb00008.x

14. França MF, Ferrari R. Burnout Syndrome and the socio-demographic aspects of nursing professionals. Acta Paul Enferm[Internet]. 2012 [cited 2016 Jun 08];25(5):743-8. Available from: http://dx.doi.org/10.1590/S0103-21002012000500015

15. Balsanelli AP, Cunha ICKO. Nursing leadership in intensive care units and its relationship to the work environment. Rev Latino-Am Enfermagem [Internet]. 2015 [cited 2016 Jun 08];23(1):106-13. Available from: http://dx.doi.org/10.1590/0104-1169.0150.2531

16. Lorenz VR, Guirardello EB. The environment of professional practice and Burnout in nurses in primary healthcare. Rev. Latino-Am. Enfermagem [Internet]. 2014 [cited 2016 Jun 08];22(6):926-33. Available from: http://dx.doi.org/10.1590/0104-1169.0011.2497

17. Flynn M, McCarthy G. Magnet hospital characteristics in acute general hospitals in Ireland. J Nurs Manag [Internet]. 2008[cited 2016 Jun 08];16(8):1002-11. Available from: http://dx.doi.org/10.1111/j.1365-2834.2006.00667.x

18. Amaral JF, Ribeiro JP, Paixão DX. Qualidade de vida no trabalho dos profissionais de enfermagem em ambiente hospitalar: uma revisão integrativa. Rev Espaço Saúde [Internet]. 2015[cited 2016 Jun 08];16(1):66-74. Available from: http://dx.doi. org/10.22421/1517-7130.2015v16n1p66

19. Duarte SCM, Stipp MAC, Silva MM, Oliveira FT. Adverse events and safety in nursing care. Rev Bras Enferm[Internet]. 2015 [cited 2017 Feb 05];68(1):144-54. Available from: http://www.scielo.br/pdf/reben/v68n1/0034-7167-reben-68-01-0144.pdf

20. Guido LA, Silva RM, Goulart CT, Bolzan MEO, Lopes LFD. Burnout syndrome in multiprofessional residents of a public university. Rev Esc Enferm USP [Internet]. 2012 [cited 2016 Jun 08];46(6):1477-83. Available from: http://www.scielo.br/pdf/reeusp/v46n6/ en 27.pdf

21. Moreira DS, Magnago RF, Sakae TM, Magajewski FRL. Prevalência da síndrome de burnout em trabalhadores de enfermagem de um hospital de grande porte da Região Sul do Brasil. Cad Saúde Pública [Internet]. 2009 [cited 2016 Jun 08];25(7):1559-68. Available from: http://dx.doi.org/10.1590/S0102-311X2009000700014

22. Kristensen TS, Borritz M, Villadsen M, Christensen KB. The Copenhagen burnout inventory: a new tool for the assessment of burnout. Work Stress [Internet]. 2005[cited 2016 Jun 08];19(3):192-207. Available from: http://dx.doi.org/10.1080/02678370500297720

23. Carlotto MS, Câmara SG. Psychometrics properties of Maslach Burnout Inventory in a multifunctional sample. Estud Psicol [Internet]. 2007[cited 2016 Jun 08];24(3):325-32. Available from: https://dx.doi.org/10.1590/S0103-166X2007000300004

24. Lake ET. Development of the practice environment scale of the Nursing Work Index. Res Nurs Health [Internet]. $2002[$ cited 2016 Jun 08];25(3):176-88. Available from: http://dx.doi.org/10.1002/nur.10032

25. Fuentelsaz-Gallego C, Moreno-Casbas MT, Gonzáles-María E. Validation of the Spanish version of the questionnaire Practice Environment Scale of the Nursing Work Index. Int J Nurs Stud [Internet]. 2013[cited 2016 Jun 08];50(2):274-80. http://dx.doi. org/10.1016/j.ijnurstu.2012.08.001

26. Kim CW, Lee SY, Kang JH, Park BH, Park HK, Lee KH, et al. Application of Revised Nursing Work Index to Hospital Nurses of South Korea. Asian Nur Res [Internet]. 2013[cited 2016 Jun 08];7(3):128-35. http://dx.doi.org/10.1016/j.anr.2013.07.003 